\title{
Toxicity Assay of Phenolic Compound Isolated from the Dichloromethane Extract of Silver Fern (Pityrogramma calomelanos)
}

\author{
Najihah, Suyatno Sutoyo*, Ismono, \\ Mitarlis \\ Department of Chemistry, Faculty of \\ Mathematics and Natural Science \\ Universitas Negeri Surabaya \\ Jl. Ketintang Surabaya, Indonesia \\ suyatno@unesa.ac.id
}

\begin{abstract}
Pityrogramma calomelanos is fern in the Polipodiaceae family that grows in tropical Asia including Indonesia. This research aims to determine the molecular structure of phenolic compound isolated from the dichloromethane extract of the silver fern's aerial part and toxicity activity test. The extraction, separation, and purification were conducted by maseration, vacuum liquid chromatography (VLC), and recrystallization. The identification of the molecular structure was analyzed using spectroscopic evidance, including UV-Vis, IR, and MS. Toxicity of isolate was tested using Brine Shrimp Lethality Test. From the separation, produced isolates as pale yellow powder with melting point of $167-168^{\circ} \mathrm{C}$. Based on spectroscopic data, isolate was 2',6'-dihydroxy-4'-methoxydihydrochalcone. It also showed toxicity against to Artemia salina in BSLT assay with $\mathrm{LC}_{50}$ of $3.957 \mu \mathrm{g} / \mathrm{mL}$. Thus isolate was categorized as highly toxic and had potential as an anticancer agent.
\end{abstract}

Keywords-Pityrogramma calomelanos, phenolic compound, dichloromethane extract, BSLT, Artemia salina

\section{INTRODUCTION}

The health problems are still a serious concern from the government of the Republic Indonesia. The main health problem causing death in humans is chronic disease. One type of chronic disease causing death especially in developing countries is cancer [1]. Cancer sufferers continue to increases year by year because the effective way for treatment have not found. Based on WHO data in 2010 cancer is the second disease cause of death after cardiovascular disease [2]. Meanwhile, based on basic health research 2013, cancer ranked seventh largest cause of death in Indonesia [3].

Medical treatment of cancer can be done by surgery, radiotherapy, and chemotherapy. One of the cancer treatments of concern is chemotherapy. However, the use of chemotherapy causes side effects because it does not only destroys cancer cells but also attack normal cells, especially cells that divide rapidly [4]. Therefore, these facts drew attention to finding alternative anticancer treatment that have selective toxicity.
Indonesia is known as the countries with the largestbiodiversity in the world that potent to be developed as raw material for medicine. Fern is one of the research object of potentially plant that has a pharmacological activity. Fern plants are widely used by Chinese, Indian and Native Americans as herbal remedies [5].

Phytochemical studies showed that fern plant is potentially source of medical plants because it produces secondary metabolite compounds and has pharmacological activity. The $n$-hexane, dichloromethane, and methanol extract of Chingia sakayensis contains some flavanoid such as pinocembrin, farrerol, and matteucinol-7-O- $\alpha-\mathrm{L}-$ arabinopyranosyl $(1 \rightarrow 6)-\beta$-glucopyranoside (miconioside A) and have values greater than $100 \mu \mathrm{g} / \mathrm{mL}$ indicated by cytotoxic activity against murine leukemia P-388 cell [6]. The methanol extract of silver fern has a cytotoxic effect on DLA (Dalton's lymphoma ascites) cells and EA (Ehrlich ascites carcinoma) cells of $16-18 \mu \mathrm{g} / \mathrm{mL}$. Meanwhile, the resulting dihydrochalcone isolate had cytotoxic effects of DLA and EA cells of $6-11 \mu \mathrm{g} / \mathrm{mL}$ and were able to inhibit the growth of $\mathrm{KB}$ cell and K-562 cell by $50 \%$ at concentration 1.1-8 $\mu \mathrm{g} / \mathrm{mL}[7]$.

Consider to the lack information of phenolic compounds isolated from dichloromethane extracts of silver fern and toxicity test for Artemia salina larveae, then the researchers were interested in conducting research about toxicity test of phenolic compound from dichloromethane extract of silver fern against Artemia salina larvae using Brine Shrimp Lethality Test method.

\section{MATERIALS AND METHODS}

\section{A. Material}

The materials used in this research were the aerial part of silver fern, $n$-hexane, dichloromethane, chloroform, ethyl acetate, methanol, $\mathrm{FeCl}_{3}, \mathrm{HCl}, \mathrm{Mg}$ ribbon, kieselgel 
60 GF-254 (Merck), precoated silica gel 60 F-254 (Merck), sea water, Artemia salina larvaes.

\section{B. Instrument}

The instruments used include a set of extraction tools with maceration method, Buchner funnel, rotary vacuum evaporator (Heidolp laborata 4001), a set of thin layer chromatography (TLC) and vacuum liquid chromatography (VLC), Fisher John melting point apparatus, IR spectrophotometer (Perkin Elmer USA 89485), UV spectrophotometer (Shimadzu Pharma Spec. UV-1700), mass spectrophotometer (Shimadzu QP2010S), and other glass tools.

\section{Sample Preparation}

Silver fern was obtained from Kletak forest, Nongkojajar, Pasuruan, East Java and had been identified by the Indonesian Institute of Sciences of the Purwodadi Botanical Garden, East Java, Indonesia. Before research was sample of the aerial part of the silver fern was cleaned and dried at room temperature. After that it was milled into a fine powder.

\section{Extraction and Isolation}

The first process is as much as $5 \mathrm{~kg}$ of dry powder of aerial part silver fern was macerated using $n$-hexane and dichloromethane. The dichloromethane extract was evaporated using vacuum rotary evaporator resulted a blackish green solid as much as $98 \mathrm{~g}$. Then, the extract was tested qualitatively using $\mathrm{FeCl}_{3}$ and Shinoda test $(\mathrm{Mg}+$ $\mathrm{HCl}$ ) showed positive results on the flavonoid compound shown by the formation of brownish green and yellowish green.

A further process of $5 \mathrm{~g}$ dichloromethane solid extract was separated by VLC method using a kieselgel 60 GF-254 (Merck) as stationary phase and mobile phase of eluent $n$ hexane, $n$-hexane-ethyl acetate and ethyl acetate. The separation yielded 114 fractions. Then separation results were monitored using thin layer chromatography with eluent $n$-hexane-ethyl acetate (4:1). Then recrystallization in the 30-80 fraction using a mixture of chloroform- $n$ hexane solvent produced flavonoid isolate. The purity of the isolate was measured by melting point and TLC using three eluent systems. Then identified qualitatively using $\mathrm{FeCl}_{3}$ and Shinoda test $(\mathrm{Mg}+\mathrm{HCl})$ and analyzed by UVVis, IR and mass spectroscopy.

\section{E. Toxicity Assay of Isolate against Artemia salina}

A portion of $2 \mathrm{mg}$ isolate were dissolved in $400 \mu \mathrm{L}$ of methanol p.a. formed concentrated primary liquid 5000 $\mu \mathrm{g} / \mathrm{mL}$. The primary liquid was pipette $1,5,10,15$, and 25 $\mu \mathrm{L}$ and each inserted in a different vial. Then left for 24 hours until the solvent evaporates, then Artemia salina larvae is inserted as much as 10 tail, then the vial is filled with sea water until the volume reaches $5 \mathrm{~mL}$ and left for 24 hours. The number of dead larvae was calculated. After that the larvae mortality results obtained were analyzed by probit using the SPSS program to determine the magnitude of $\mathrm{LC}_{50}$.

\section{RESULT AND DISCUSSION}

The $5 \mathrm{~kg}$ dried powder of aerial part silver fern is extracted by maceration using $n$-hexane and dichloromethane as successively solvent. The residue of maceration with $n$-hexane dried by aerated. Then the residue is macerated with dichloromethane (8L x 3 ) for 24 hours at room temperature. After that evaporated with rotary vacuum evaporator obtained by a blackish green solid extract of $98 \mathrm{gr}$.

After that it was tested qualitatively with $\mathrm{FeCl}_{3} 5 \%$ yielding brownish green, while with addition $(\mathrm{Mg}+\mathrm{HCl})$ yielding yellowish green. Then $5 \mathrm{gr}$ of dichloromethane solid extract were separated by vacuum liquid chromatography method using a kieselgel 60 GF-254 (Merck) stationary phase and mobile phase of eluent $n$ hexane, $n$-hexane-ethyl acetate and ethyl acetate. From the results of the separation obtained 114 fractions.

After that the results of the separation from vacuum liquid chromatography monitored by TLC with eluen $n$ hexane-ethyl acetate (4:1) produced a stain with the same $\mathrm{Rf}$ value at fraction 58-65. In the fraction, was done by combined chloroform solvent and evaporated to a rotatory evaporator was obtained by a blackish green solid of 385.9 $\mathrm{mg}$. Then recrystallized using a mixture of chloroform- $n$ hexane solvent obtained a pale yellow powder isolate of $75.5 \mathrm{mg}$. Then the purity of the isolate was measured by melting point and TLC using three eluent systems. The result of melting point measurement using Fisher John melting point apparatus obtained for $167-168{ }^{\circ} \mathrm{C}$ with an interval of $1{ }^{\circ} \mathrm{C}$. In TLC three eluents system with eluent ratio $n$-hexane: ethyl acetat $(4: 1) ; n$-hexane: ethyl acetat (9:1) and chloroform:ethyl acetat (9:1); showed a single stain with $\mathrm{Rf}$ of each 0.51 and 0.14 and 0,77 . So that the isolated compound were pure categorized which supported by the measurement of melting point showed the interval of melting point $1{ }^{\circ} \mathrm{C}$. The isolated compound identified using $\mathrm{FeCl}_{3}$ yielding greenish brown, while with $(\mathrm{Mg}+\mathrm{HCl})$ yielding a yellow. This indicates the presence of flavonoid in the isolated compound.

The isolated compound was analyzed using UV-Vis spectroscopy with methanol solvent obtained maximum absorption at $\lambda_{\text {maks }} 285$ and 330 (sh) nm; $(\mathrm{MeOH}+\mathrm{NaOH})$ : 295 and $364(\mathrm{sh}) \mathrm{nm} ;\left(\mathrm{MeOH}+\mathrm{AlCl}_{3}\right): 305$ and $374(\mathrm{sh})$ $\mathrm{nm} ;\left(\mathrm{MeOH}+\mathrm{AlCl}_{3}+\mathrm{HCl}\right): 288$ and 375 (sh) nm; $(\mathrm{MeOH}$ $\left.+\mathrm{NaOAc}+\mathrm{H}_{3} \mathrm{BO}_{3}\right): 285 \mathrm{~nm}$ and $(\mathrm{MeOH}+\mathrm{NaOAc}): 285$ $\mathrm{nm}$. The IR spectrum shows the functional group in the absorption region $\mathrm{cm}^{-1}$ : 3259.81; 3022.55; 2918.40; 
$2848.96 ; 1648.41 ; 1595.18 ; 1527.67 ; 1442.80 ; 1427.37$; $1365.65 ; 1301.99 ; 1213.27 ; 1195.91 ; 1163.11 ; 1080.17$; 1039.67

The UV-Vis spectroscopic analysis of the isolated compound in methanol showed the maximum absorption at $285 \mathrm{~nm}$ of band II and $330 \mathrm{~nm}$ of band I. The addition of $\mathrm{NaOH}$ reagent showed by not significant of the bathochromic shift of band II that is $10 \mathrm{~nm}$ [9]. This showed there is no free hydroxyl group at C-4' in the isolate. In addition $\mathrm{AlCl}_{3}$ reagent showed bathochromic shift of band II at a peak $305 \mathrm{~nm}$ so that have a phenolic hydroxyl group at $\mathrm{C}-2$ '. Then adding $\mathrm{AlCl}_{3}+\mathrm{HCl}$ and $\mathrm{NaOAc}+\mathrm{H}_{3} \mathrm{BO}_{3}$ reagent showed by not changing the bathochromic shift of band II so that the isolate did not have the ortho-dihydroxy. After that adding $\mathrm{NaOAc}$ reagent showed that isolate did not have a free hydroxyl group at C-4' because there was no bathochromic shift of band II.

Based on IR spectroscopic analysis showed that isolate was a flavonoid having hydroxyl group (3259.81), aromatic C-H (3022.55), chelated $\mathrm{C}=\mathrm{O} \quad(1648.41)$, strain $\mathrm{C}-\mathrm{O}$ (1248.87; 1195.91; 1163.11; 1080.17 and 1039.67), aromatic $\mathrm{C}=\mathrm{C}$ (1599 and 1527.67), alkyl C-H (2918.40 and 2848.96), and vibration of C-H alkyl (1442.80; 1427.37; 1365.65 and 1301.99) showed the vibration of $\mathrm{C}-\mathrm{H}$ alkyl. The existence of $\mathrm{OH}$ in IR spectroscopy analyzation shows.

Based on UV-Vis and IR spectrum is known that the isolated compound result is flavonoid compound group dihydrochalcone characteristic type as in Fig 1:

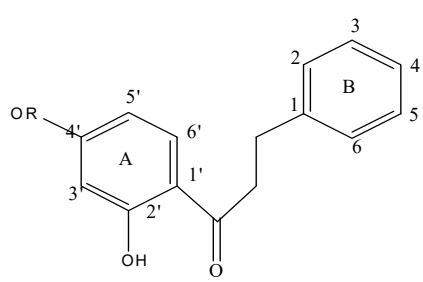

Fig 1. Dihydrochalcone compound

Result of mass spectrum analysis, isolate result has molecular ion peak at $\mathrm{m} / \mathrm{z} 272$ with retention time (Rt) of 31.962 minutes and percent area of $85.08 \%$. The compound has a fragmentation ion at $\mathrm{m} / \mathrm{z} 272\left(\mathrm{M}^{+}\right), 255,168,167$, $140,137,124,111,104,91,77,65,51,39,28$. The A ring has a benzoil group indicated by the peak at m/z 167 . While the $\mathrm{B}$ ring has 2-phenyl ethyl group showed by the peak at $\mathrm{m} / \mathrm{z}$ 104. Based on the result UV-Vis, IR and GCMS spectrum isolate can be identified as flavanoid compound namely 2',6'-dihydroxy-4'-methoxy dihydrochalcone as in Fig 2:

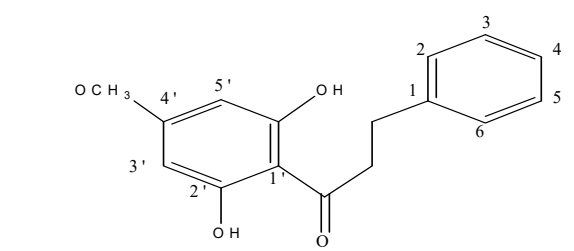

Fig 2. 2',6'-dihydroxy-4'-methoxy dihydrochalcone

The toxicity test of isolated compound from dichloromethane extract of aerial parts of fern plant was done using BSLT method with Artemia salina larvae of 48 hours age in the form of naupli. Result of the isolate toxicity test is shown in Table 1 .

TABLE 1. TOXICITY ASSAY OF ISOLATE AGAINST ARTEMIA SALINA

\begin{tabular}{|c|c|c|c|}
\hline $\begin{array}{c}\text { Concentration } \\
\text { of sample } \\
\text { (ppm) }\end{array}$ & $\begin{array}{c}\text { Initial } \\
\text { amount of } \\
\text { A. salina } \\
\text { Leach }\end{array}$ & $\begin{array}{c}\text { Lethal } \\
\text { amount } \\
\text { average of } \\
\text { A. salina } \\
\text { Leach }\end{array}$ & $\begin{array}{c}\text { Lethal } \\
\text { percentage } \\
\text { of } \text { A. salina } \\
\text { Leach (\%) }\end{array}$ \\
\hline 1 & 10 & 3 & 30 \\
\hline 5 & 10 & 5,33 & 53,3 \\
\hline 10 & 10 & 6,33 & 63,3 \\
\hline 15 & 10 & 7 & 70 \\
\hline 25 & 10 & 7,67 & 76,7 \\
\hline
\end{tabular}

Based on Table 1, the probit analysis using the SPSS program of the isolate produced $\mathrm{LC}_{50}$ value of $3.957 \mu \mathrm{g} / \mathrm{mL}$ so that the compound was categorized as having toxicity level is very toxic [10]. If a compound has cytotoxic properties then the compound is potential as an anticancer compound.

IV. CONCLUSIONS

Flavonoid compounds isolated from the dichloromethane extract aerial part of the silver fern namely 2',6'-dihydroxy-4'-methoxy dihydrochalcone. From the separation, produced isolates of pale yellow powder as much as $75.5 \mathrm{mg}$ with m.p. of $167-168^{\circ} \mathrm{C}$. And the 2',6'dihydroxy-4'-methoxy dihydrochalcone shows the chracteristics of toxic to Artemia salina larvae in the BSLT method with the value of $\mathrm{LC}_{50}$ about $3.957 \mu \mathrm{g} / \mathrm{mL}$ categorized as having toxicity very toxic.

\section{ACKNOWLEDGMENT}

We thanks the Directorate of Research and Innovation Empowerment, Directorate of Empowerment for Research and Development, the Ministry of Research, Technology and High Education, Indonesia, for financial support through the Superior Fundamental Research of Higher Education Grant 2018.

\section{REFERENCES}

[1] E. P. Sarafino, Health Psychology: Biopsychosocial Interactions, $5^{\text {th }}$ ed. New York: John Wiley \& Sons, 2006.

[2] World Health Organization, Infant Mortality. http://www.who.int/cancer/en/, Accessed 15 November 2017.

[3] Indonesian Ministry of Health, Basic Health Research, Indonesian Ministry of Health's Research and Development Agency, Jakarta, 2013. 
[4] N. Sutandyo, Chemotherapy, Benefits and Side Effects (Kemoterapi, Manfaat dan Efek Samping), Jakarta: Dharmais Cancer Hospital, 2007.

[5] C. H. Lee and S. L. Shin, Functional Activities of Fern for Human Health, Issues and Applications, Chapter 24, Business Media, Springer Science, 2011.

[6] S. Sutoyo, G. Indrayanto, and N. C. Zaini, "Flavonoid from the Chingia sakayensis (Zeiller) Holtt and evalution of their cytotoxicity against murine leukemia P-388 cells," Natural Product Communications, vol. 2(9), pp. 917-918, 2007.
[7] K. Sukumaran and R. Kuttan, "Screening of 11 fern for cytotoxic and antitumor potential with special reference to Pityrogramma calomelanos," Ethnopharmacology, vol. 34, pp. 93-96, 1991.

[8] K. R. Markham, Techniques of Flavonoid Identification (Cara mengidentifikasi flavonoid), Translator K.Padmawinata, Bandung, ITB, 1988.

[9] B. N. Meyer, N. R. Ferrigni, J. E Putnam, L. B. Jacobsen, D. E. Nichols, and J. L. McLaughlin, "Brine shrimp: A convient general bioassay for active plant constituents", Planta Medica, vol. 45, pp. 3134, 1982. 